\title{
Can punishment bring peace? Penal substitution revisited
}

\section{Steve Holmes}

School of Humanities, King's College London, steve.holmes@kcl.ac.uk

Recently, I attended a conference on the theme 'theologies of the cross'. I gained much from it in various ways, but one feature concerned me: in reading the papers, and listening to discussions, it became rather clear that, whilst the various contributors might or might not agree, or even be sure about, what they did believe about the cross, they were all both united and certain on what they didn't believe in - the traditional Reformed and Evangelical idea of penal substitution. ${ }^{1}$ Now, I confess that I had no particular commitment to this idea. I knew of no exegetical or theological reason to demand that we hold on to it, or to suggest that our account of the atonement would necessarily be lacking something vital if we did not express it in this way. Penal substitution was a way of talking about the cross with which I was familiar, but to which I was not committed. Temperamentally, I had tended to avoid it: as far as I can judge, the dominant way of talking about the cross in my preaching has been in terms of combat with, and victory over, the evil powers of sin and death and hell; it is not a theme I have touched on much in my academic writing. Penal ideas are common, however, in the liturgy and (particularly) hymnody of my church tradition: 'Bearing shame and scoffing rude/In my place condemned he stood'; 'All our pride, all our greed, all our fallenness and shame, and the Lord has laid the punishment on him. ${ }^{2}$ I have never seen any reason to object to such songs. So, to be at a conference where there was near unanimity that, whatever else we were going to say about the cross, we would begin by dismissing this tradition, was of interest and concern to me.

${ }^{1}$ Behind this paper lie some comments I made in the plenary session at the end of that conference, and an email from Colin Gunton suggesting that I should write them up into something publishable - a suggestion to which I had not replied when Colin died so suddenly. Earlier versions of the paper were read at the Research Institute in Systematic Theology seminar at King's College, London; a Baptist theological consultation at Regent's Park College, Oxford, and the postgraduate seminar of Spurgeon's College. In each case I received helpful comment and criticism. In addition, some comments on the paper by Dr. Mike Higton have helped me greatly to clarify my thoughts.

2 Philipp Bliss, 'Man of Sorrows'; Graham Kendrick, 'Come and See’. 
I want, therefore, in this paper to offer a programmatic account of a defence of this tradition through a series of steps. The first, and briefest, step will be to sketch an account of what we are doing when we theologise about the atonement. Next, I want to examine a classical statement of penal substitution to demonstrate precisely what is or is not claimed in talking about the cross this way; this will lead to a consideration of which of the common criticisms offered are significant, and which are directed at misreadings, and so can be safely dismissed. Then I will attempt defences against the substantive criticisms that remain.

It is a commonplace of recent theological writing on the cross to consider the various ways in which preachers, theologians, and even the Scriptures talk about the mechanics of the atonement as a series of images, models or metaphors that are valuable insofar as they manage to convey something of the truth of what was going on at Calvary, but which are not meant to be understood as literal mechanistic accounts of the event and its effects. ${ }^{3}$ The event of the cross, it seems to me, is necessarily sui generis, and so to suggest that any one of the traditional models is an accurate and full account of that event must be wrong - this is not merely one, even the pre-eminent one, in a series of inspirational acts of self-sacrifice, nor is it an illustration of a more general principle of substitution or representation, whether that is constructed in terms of an anthropological account of sacrifice or a legal account of corporate responsibility. Rather, the cross is a single decisive event that evades such categorisation precisely because it is so basic to any properly theological account of the nature of true humanity, true justice, true sacrifice, true relationship, or a host of other realities. ${ }^{4}$ Each model illuminates something of that event, whilst simultaneously distorting it in some way. They are, as Gunton says, metaphors, at once like and unlike the thing which they describe. If penal substitionary language for the atonement is defensible, it will be in these terms and not others.

3 For instance, Colin E. Gunton, The Actuality of Atonement: A Study of Metaphor, Rationality and the Christian Tradition (Edinburgh: T\&T Clark, 1988); see especially pp. 27-52, where Gunton defends the use of 'metaphor' to describe the different atonement theories. The point is general, although the precise terminology adopted varies: Paul S. Fiddes, Past Event and Present Salvation: The Christian Idea of Atonement (London: DLT, 1989) uses the word 'images'; F. W. Dillistone, The Christian Understanding of Atonement (London: SCM, 1968) uses 'analogues' and 'parables'; John McIntyre, The Shape of Soteriology (Edinburgh: T\&T Clark, 1992) offers 'models'. This list is very far from exhaustive.

${ }^{4}$ See my God of Grace and God of Glory: An Account of the Theology of Jonathan Edwards (Edinburgh: T\&T Clark, 2000), pp. 163-4 for some discussion of this point. 


\section{Penal substitution: towards a restatement}

It is often asserted that there is no clear statement of penal substitution in the Scriptures. I think this assertion is open to challenge, ${ }^{5}$ but for the purposes of this paper, I will simply accept it. This is not yet a good reason not to use an account of penal substitution to describe and illuminate what goes on at Calvary. Under the guidance of the Spirit, the Church has chosen to express its beliefs about God's tri-personal existence, and about the unity of true humanity and true divinity in the person of Christ, using conceptual schemes that are not found in Scripture, but are rather borrowed from the Academy of Athens and adapted to be of service; what good theological reason can be advanced to suggest that the Roman law court could not furnish a similar conceptual scheme for describing the atonement, assuming that one can be found which (with appropriate adjustment) can be put to service?

Perhaps the classical statement of penal substitution comes in the writings of John Calvin. Before examining what Calvin has to say, I want to look at some of the antecedents of his account. It is worth noting explicitly that, despite what is sometimes asserted by opponents of the scheme, Anselm's account in Cur Deus Homo cannot properly be described as penal substitution. ${ }^{6}$ The conceptual motor there is not punishment due as a result of a failure to obey legislation; instead, Anselm's scheme adapts feudal accounts of the honour due from a vassal to a liege-lord, and the satisfaction offered is a way of making good the honour that was due. ${ }^{7}$ It is explicitly not a punishment: Anselm poses the famous dilemma aut poena aut satisfactio precisely to indicate that, within his conceptual scheme, the idea of God punishing sin is unthinkable, as it would indicate that his project of creation had

5 Emil Brunner's assertion indicates one way in which the discussion might proceed: ' $\mathrm{t}$ ] wo series of statements of a parabolic nature determine the scriptural message concerning the fact of the atonement: firstly, the parables which deal with the payment of debts, which are taken from the practice of law, with their ideas of penalty and satisfaction; and secondly, analogies drawn from the practice of the cultus, with their emphasis upon the sacrifice and the shedding of blood' (The Mediator, trans. Olive Wyon (London: Lutterworth, 1937) p. 455). Again, John McIntyre comments 'there is strong prima facie support for the view that sacrifice and penalty are not to be separated off from one another, the latter providing an essential element in the interpretation of the former ...' (The Shape of Soteriology (Edinburgh: T\&T Clark, 1992), p. 44).

${ }^{6}$ Paul Fiddes recognises this - see Past Event, p. 97.

7 I have written more fully on Anselm's arguments in Cur Deus Homo in 'The Upholding of Beauty: A Reading of Anselm's Cur Deus Homo' Scottish Journal of Theology 54.2 (2001), pp. 189-203, reprinted (with minor adjustments) as chapter 3 of my Listening to the Past: The Place of Tradition in Theology (Carlisle: Paternoster, 2002). 
failed. ${ }^{8}$ That is, Anselm makes sense of the atonement through drawing on the metaphor of the hierarchical ordering of his society, and the right maintenance of that order. Arguably, Anselm's account is not even properly described as substitutionary, as the scheme only makes sense if the Godman acts in solidarity with the whole of creation, rather than in its place. Nonetheless, Anselm's account lends itself to language of God's majesty being offended, if that language is carefully specified to take account of God's impassibility, and of a necessary satisfaction to meet the offence. It is only a short step from here to penal substitution as Calvin formulated it. In particular, Anselm, like Calvin, assumes that sin requires satisfaction - that God cannot simply forgive, without some act of reparation taking place. ${ }^{9}$ The (often heated) denial of this premise is at the heart of many modern objections to notions of penal substitution (as it was to Abelard's response to Anselm), and so Anselm's arguments can be deployed to defend a central feature of Calvin's account, even though he deploys them to a different end.

A second background for Calvin's account might be found in the strong Biblical tradition of metaphors of sacrifice. Christ is the spotless lamb of God, slain on behalf of the people of God so that the avenging angel might pass over those whose households are marked with his blood, or he is the scapegoat slain as an offering of atonement, with the sins of the people symbolically laid on his head so that his death may mark their forgiveness. (In passing, it is worth considering the question of whether the Old Testament sacrificial system should be read as a typological prefiguring of Christ's death. If this were to be the case, then my initial comments about metaphor would need a certain amount of nuancing, in that an account of the events of Calvary built on sacrifice would be privileged in certain ways. Whilst I think typology has more going for it as a method of Biblical exegesis than is usually allowed these days, I see problems here. In particular, I suspect that the sustained later critique of the sacrificial cult in the prophets and the wisdom literature would make a straightforward typological privileging difficult.)

Some, at least, of these Biblical metaphors are explicitly substitutionary. Consider, for example, Abraham, who 'offered up [the ram] as a burnt offering instead of his son' (Gen. 22:13 NRSV; the Hebrew is thachath). Famously, the theological logic of the sacrificial system demanded in the pentateuchal law codes is somewhat opaque, but many recent commentators

${ }^{8}$ See Cur Deus Homo I.xv, xix, xxv; also my Upholding of Beauty, p. 197 (art.)/44 (book).

9 On which see Cur Deus Homo I.xii, where Anselm offers three arguments to this end, the first two turning on the concept of the 'right ordering' of the universe (quoniam recte ordinare...), which makes certain acts of God 'unfitting' (quod Deo non convenit); the third on God's faithfulness. 
suggest that it is best understood as substitutionary. Gordon Wenham, for instance, asserts that 'in giving the animal to God, the worshipper is reminded that he should die for his sins had the animal not taken his place'. ${ }^{10}$ Again, Erhard Gerstenberger describes 'the ritual transfer of sin through "hand leaning" [i.e., the worshipper's placing of a hand upon the sacrificial animal]', ${ }^{11}$ and notes that kipper, 'effecting atonement', is a word that occurs more times (50) in Leviticus than in the rest of the Old Testament together (43 occurrences), which he suggests 'proves the central significance of propitiatory sacrificial practice at least for certain redactors of the priestly tradition' ${ }^{12}$ The text that is perhaps most pregnant with theological meaning for describing the sacrificial system in the Pentateuch, Lev 17:11, asserts that 'the life of the flesh is in the blood; and I have given it to you for making atonement for your lives on the altar; for, as life, it is the blood that makes atonement' (NRSV). Whilst not perhaps insisting on a life-for-life substitution at the heart of the sacrificial system, the text certainly invites that reading. The general account seems to suggest that: the committing of sin somehow makes the sinner liable to certain consequences, as discussed above; and that these consequences can somehow be turned aside through the ritual transfer of the sin to a sacrificial animal, and the offering of its blood/life to God. ${ }^{13}$

More interesting, perhaps, is the widespread exegetical agreement that the sacrificial system presumes that sin causes some liability for punishment, which cannot be passed over by God, but must somehow be turned away. This is the Biblical basis for Anselm's demand for satisfaction, or Calvin's guilt that cannot be ignored. So, for instance, John E. Hartley speaks of 'the principle of retribution, i.e., every sin is pregnant with its own consequences'. ${ }^{14}$ Gerstenberger traces a similar, but more personalised, conception: '[a]ny

10 Gordon J. Wenham, Numbers (Tyndale Old Testament Commentary) (Leicester: IVP, 1981), p. 204. Wenham describes this reconstruction as 'the most probable view'. In the same discussion he quotes approvingly Leach's Culture and Communion (Cambridge: Cambridge University Press, 1976) as saying 'The plain implication is that, in some metaphysical sense, the victim is a vicarious substitution for the donor himself' (p. 89). See further Wenham's The Book of Leviticus (Grand Rapids, MI: Eerdmans, 1979).

11 Gerstenberger, Erhard S. Leviticus: A Commentary (trans. Douglas W. Stott) (Louisville, KT: WJKP, 1996), p. 35.

12 Gerstenberger, Leviticus, p. 27.

13 On this see particularly N. Kiuchi, The Purification Offering in the Priestly Literature: Its Meaning and Function (JSOTS Supp. Series 56) (Sheffield: Sheffield Academic Press, 1987), passim, but particularly pp. 101-9 and 162, where strong exegetical arguments for understanding the sacrificial mechanism as explicitly substitutionary are developed.

${ }^{14}$ Hartley, John E. Leviticus (Word Biblical Commentary) (Dallas, TX: Word, 1992), p. lxxi. 
misdeed ... provokes God's anger ... The deity is disturbed, enraged ... The deed represents not only a legal breach, but also an insult ... Yahweh must react as a person... condemnation thus does not emerge from any court procedure... [but] as an almost "automatic" counterreaction on the part of God ...' ${ }^{15}$ Gerstenberger regards the use of sacrifice in turning aside such divine anger as a 'primitive' conception ('prehistoric notions of faith ... [in which] blood is considered to be a magical substance efficacious in and of itself' ${ }^{16}$ A. T. Hanson, in a fascinating consideration of Biblical accounts of God's wrath, suggests a development through the Old Testament period from Gerstenberger's primitive and personalised picture to a much more impersonal principle or retribution, similar to Hartley's account. ${ }^{17}$

I confess to being rather unconvinced by most such attempts to describe this or that Old Testament theme as 'primitive'. Partly, this is down to a degree of scepticism about the confident assigning of this or that verse to a particular, and datable, stage of redaction; more fundamentally, one does not need a great knowledge of history to find the equation 'older $=$ more primitive' - and its implied converse, 'newer = more advanced/civilised' simply bizarre. That an ethical or theological conception was current ten centuries before Christ is no proof that it is wrong, even before any account of revelation or inspiration is deployed. The argument I will be developing will, as it happens, follow the 'impersonal' line here, largely as a result of some commitments learnt from Anselm concerning the doctrine of God, but this is not as a result of any rejection of certain Biblical themes as 'primitive' so much as an exegetical and theological judgement. Still, sacrifice here is understood as a necessary way of turning away the inevitable consequences of sin, which are real and serious, and cannot just be waived.

I suggest, without having space to argue the point here, that the key moment in the development of a penal account came when sacrificial pictures no longer communicated meaningfully, and penal metaphors were available and helpful. It may be that sacrificial images are the central way in which the New Testament talks about the death of Christ, but in cultures (such as ours) which have no tradition of sacrificial practice, such imagery seems merely

15 Gerstenberger, Leviticus, p. 57.

16 Gerstenberger, Leviticus, pp. 59-60; see also the discussion on pp. 60-1 as to why such primitive ideas were revived in the post-exilic period when the final redaction of Leviticus is presumed to have taken place.

17 Anthony Tyrrell Hanson, The Wrath of the Lamb (London: SPCK, 1957), pp. 1-40. Hanson finds the Chronicler's view of wrath to be almost wholly impersonal, in contrast to some of the earlier strata of OT writings. In arguing for this development, he is slightly embarrassed by the (unquestionably late, and highly personalised) apocalyptic passages in the prophets. 
opaque. Even if we accept that the sacrifices of the Old Testament cultus were intended as types of Christ's death, and so that they have a privileged position in its interpretation, still we are faced with two problems, one cultural, one theological. The cultural problem is that sacrifice no longer means anything to us today, and so we are faced with an analogous problem to the one we have with the privileged Greek metaphysical accounts of the Trinity: we might know what orthodoxy is, but it takes either sustained and patient explanation, or a series of more immediately comprehensible supporting metaphors, before it can be understood by anyone without considerable specialised knowledge.

In non-sacrificial cultures, then, different imagery might be necessary to explain or illuminate the events of Calvary, and I suggest that the rise of penal accounts may be understood in these terms: they are a way of making sense of the Biblical language of guilt- and sin-bearing substitutionary sacrifice in a context where sacrifice itself is what has been called a 'dead metaphor'. ${ }^{18}$ The fact that any examination of evangelical hymnody will demonstrate how closely intertwined sacrificial and penal imageries are in that tradition of spirituality, perhaps lending support to my thesis, ${ }^{19}$ as does Foucault's (and others') recognition of the deeply ingrained ritualism of criminal justice systems in the modern West. ${ }^{20}$ The running together of different atonement metaphors like this is not inappropriate, of course: it is also entirely characteristic of the New Testament texts, which famously pile their

18 This would particularly be the case if, as I suspect, sacrifice functions as a semiotic event which cannot be reduced to words without losing something of its symbolic logic. In this case, no amount of discussion of sacrificial systems can make sacrificial metaphors live in a non-sacrificial culture in quite the way they did when first used. The sensory experience - sight, sound, smell - of hot blood spurting from a fresh knife wound communicates in a way that description of it, however powerful, cannot replicate.

19 Consider Bliss's stanza, quoted in part above: 'Bearing shame and scoffing rude/In my place condemned he stood/Sealed my pardon with his blood/Alleluia! What a Saviour!' The second line is unquestionably penal in its imagery: 'condemned' is the language of the law court; the third, by contrast, with its emphasis on blood, is more naturally read as sacrificial. The same feature, of the two images intertwining, is common in the new evangelical hymnody as well: consider 'I believe there is a God in heaven who paid the price for all my sin/Shed his blood to open up the way for me to walk with Him/Gave His life upon a cross/Took the punishment for us/Offered up Himself in love/Jesus, Jesus' (Dave Bilbrough) or 'My condemnation falls on Him./This love is marvellous to me,/His sacrifice has set me free' (Graham Kendrick).

20 Michel Foucault, Discipline and Punish (trans. Alan Sheridan) (London: Allen Lane, 1977). See also Rene Girard, Violence and the Sacred (trans. Patrick Gregory) (London: John Hopkins University Press, 1977), p. 21. 
images on top of one another in a sometimes bewildering profusion. This intertwining of different images is also, finally, characteristic of John Calvin's accounts of the atonement, and so is the context in which a penal account first comes to its fullest flower. ${ }^{21}$

The relevant chapters of the Institutes ${ }^{22}$ are II.xv-vii. II.xv treats of the threefold office, which identifies the several parts of Christ's saving work. As prophet, Christ reveals to us all that is 'worth knowing' (II.xv.2); as king, Christ reigns forever to provide for our needs and protect us, and will return to judge the living and the dead (II.xv.3-5); as priest, Christ reconciles us to God through his self-offering as a sacrifice, and through his present intercession for us (II.xv.6). The essence of Christ's work, however, is spelt out in ch. xvi, which begins, 'What we have said so far concerning Christ must be referred to this one objective: condemned, dead, and lost in ourselves, we should seek righteousness, liberation, life and salvation in him ...' (II.xvi.1). This long chapter is devoted to 'earnestly ponder[ing] how he accomplishes salvation' (II.xvi.1), returning once more to the opening theme of the Institutes, and offering a programmatic statement of penal substitution: ' $[n]$ o one can descend into himself and seriously consider what he is without feeling God's wrath and hostility toward him. Accordingly he must anxiously seek ways and means to appease God, and this demands a satisfaction. No common assurance is required, for God's wrath and curse always lie upon sinners until they are absolved of guilt. Since he is a righteous Judge, he does not allow his law to be broken without punishment, but is equipped to avenge it' (II.xvi.1). Here, once again, is the idea that sin cannot be ignored, but demands satisfaction before it may be forgiven.

The first three sections are devoted to clearing away a difficulty that Calvin perceives, which is of relevance to my discussion: Scripture speaks of God in his wrath regarding people as cursed, as his enemies until they are saved through Christ, ${ }^{23}$ and yet this cannot be the whole truth, or else why would God have acted in Christ to save in the first place? Calvin's answer is that God, to use the trite slogan, hates the sin whilst loving the sinner. 'All of us . . have

21 Robert A. Peterson, Calvin and the Atonement (Fearn: Christian Focus Publications, 1983) suggests that Luther and Zwingli had both developed penal accounts, but quotes H.D. McDonald's assertion that 'it belongs to Calvin to have given the penal substitutionary doctrine of the atonement a compelling statement', pp. 88-9.

22 I am quoting the Battles translation, and using the Barth and Niesel edition of the Latin: John Calvin, The Institutes of the Christian Religion (2 vols.) (ed. John T. McNeill; trans. Ford Lewis Battles) (London: SCM Press, 1960); Joannis Calvini: Opera Selecta (5 vols.) Petrus Barth et Guilelmus Niesel (eds.) (Christian Kaiser, tertio edn, 1967-74).

${ }^{23}$ Calvin cites Rom. 5:10, Gal. 3:10,13 and Col. 1:21-2. The point is hardly exceptional, however. 
in ourselves something deserving of God's hatred ... [b]ut because the Lord wills not to lose what is his in us, out of his own kindness he still finds something to love. However much we may be sinners by our own fault, we nevertheless remain his creatures...' (II.xvi.3). Scripture speaks powerfully of God's hatred and enmity towards the unconverted person to make us sensible of the true value of God's gift of salvation in Christ (II.xvi.2), but the deeper truth is God's prevenient grace: 'while we were still sinners, Christ died for us'.

Two aspects of this discussion are interesting: the echoes of Anselm's argument that God in some important sense cannot but act to save, and the relativising of God's wrath to the sinner. Here, in the classical account of penal substitution, the first note is necessarily grace, God's love towards his sinful creatures. His wrath burns, it is true, but that is not the basic reality. Any discussion of penal substitution which asserts that the basic reality is the wrath of God is a caricature: as Calvin demonstrates, although the tradition will take this reality with the utmost seriousness, the logic of the position cannot work if the grace and love of God is not prior.

After disposing of this difficulty, Calvin turns to the way in which Christ has redeemed us, and offers an exposition of the relevant clauses of the Apostles' Creed. His first point ('born of the virgin Mary') is to note that Christ's whole life of obedience was redemptive, citing the relevant Scriptures. The only mechanistic comment in this paragraph, however, is the enigmatic statement 'from the time when he took on the form of a servant, he began to pay the price of liberation in order to redeem us' (II.xvi.5). Calvin here offers no explanation of how his life is such a payment. ${ }^{24}$ He then, following the Creed, moves straight from the fact of Christ's life to his trial ('suffered under Pontius Pilate'). Calvin makes much of this, as a historical and narrative image of Christ being condemned on our behalf: 'Scripture first relates Christ's condemnation under Pontius Pilate... to teach us that the penalty to which we were subject had been imposed on this righteous

${ }^{24}$ Later in the same section he makes the point that 'no proper sacrifice to God could have been offered unless Christ ... subjected and yielded himself wholly to his Father's will'. This is true, of course, but makes Christ's life of obedience a precondition for paying the penalty, not a part of the payment itself. In II.xii.3 there is a suggestion that Christ takes Adam's place and lives the life that Adam should have lived. Again, however, the redemptive mechanism is not clearly spelt out (check) or, rather, it is: 'to take Adam's place... and to pay the penalty that we had deserved ...'; the mechanism is penal substitution. Robert Peterson notes that Hans Scholl has advanced the thesis that Calvin follows Irenaeus's account of recapitulation, but offers good reasons for refusing to accept this argument. Peterson, n. 6 on p. 62, citing Scholl, Calvinus Catholicus (Freiberg: Herder, 1974). 
man' (III.xvi.5). Calvin expands on this point at length: Christ had to die the way he did as an image, a prophecy, a type perhaps, of the atonement he was making as our penal substitute. The section ends 'This is our acquittal: the guilt that held us liable for punishment has been transferred to the head of the Son of God. We must, above all, remember this substitution, lest we tremble and remain anxious throughout life - as if God's righteous vengeance, which the Son of God has taken upon himself, still hung over us' (III.xvi.5).

Not only the occasion of Christ's death, but its form is illustrative of this point, and so in expounding 'crucified', Calvin notes that to die on a cross was to be accursed by God, according to the Deuteronomic law code. Calvin's discussion of this point shifts the metaphor slightly, from penalty to sacrifice, although the two are fairly intertwined through this section. Next follows 'descended into hell'. Calvin famously interprets the decensus as describing the sufferings of Christ on the cross. What is not always noted is why Calvin prefers this interpretation. By teaching that Christ experienced the sufferings of hell on the cross, Calvin is seeking to insist that the just penalty that has been declared against sinners was transferred to Christ. ${ }^{25}$ In interpreting 'on the third day he rose again from the dead', Calvin focuses on the motif of victory: in discussing Christ's ascension and heavenly session, the atoning act of intercession; in Calvin's creedal narrative soteriology, then, there is more than just penal substitution, but this model of the atonement plays a significant part.

\section{On justice and satisfaction}

There are several standard complaints about penal substitution, mostly concerning either the account of God offered or the allegedly inappropriate visions of justice that the model presupposes. It is variously suggested that God is not constrained by any demands of justice, and can and does simply forgive out of love, so there is no need for satisfaction; that penal substitution pictures an improper separation between Father and Son; that visions of God's anger needing propitiation are unworthy; or that in any case for the Father to punish an innocent substitute in place of the guilty party is fundamentally unjust. Each of these accusations is serious, in that if any one of them is true, then it would be fair to say that penal substitutionary accounts obscure, rather than illuminate, the reality of the cross. Let me look at them in turn, using the resources I have developed so far.

The first argument begins with an assertion that concepts of justice are merely inappropriate to God; God can chose to forgive. Kathryn Tanner, for instance, argues on the basis of 'the unconditionality of God's giving' that

25 This is clear in II.xvi. 10. 
'the cross saves us from the consequences of a debt economy in conflict with God's own economy of grace by cancelling it'. ${ }^{26}$ In liberation-influenced theologies, the same point is made, with the suggestion that what is needed is not forgiveness for past sins, but an ardent amendment of life devoted to siding with the oppressed, not the oppressors. The classical response to such charges is that of Anselm to Boso, who offered the same point in Cur Deus Homo I.12. Why can God not simply forgive sin, or, indeed, as Boso offers at another point, why is a life lived in repentance and service to God - whether Boso's offer of devoted monastic asceticism, or the modern offer of living with the oppressed and fighting for liberation - not sufficient for God to forgive?

We might begin a response by noting that penal substitution is a metaphor that operates in the realm of law, and that it is of the essence of law that it cannot simply be set aside. A short walk from where I live is Runnymede, and the memorials to the signing of the still-celebrated Magna Carta. It is still celebrated, because it codifies the revolutionary idea that there are some things that even kings cannot do: there is a law that is not merely the decree of fiat of whoever happens to hold sovereignty, but which is somehow, within the nature of things, binding on all human beings. In modern parlance, certain people - only, in Magna Carta - have rights that are inalienable: 'At Runnymede, at Runnymede, your rights were won at Runnymede. No freeman may be fined or bound, or dispossessed of freehold ground, except by lawful judgement found, and passed upon him by his peers - forget not, after all these years the charter signed at Runnymede', to quote Kipling's doggerel summary. ${ }^{27}$

The penal tradition of talking about the atonement must be understood as assuming this basic intuition. God cannot just waive the law because it is the essence of law that it cannot just be waived. The question of how

26 Kathryn Tanner, Jesus, Humanity and the Trinity: A Brief Systematic Theology (Edinburgh: T\&T Clark, 2001), p. 88.

27 Rudyard Kipling, 'The Reeds of Runnymede'. In passing it is worth noting that this instinct, that there is an order to which all people, however powerful, are responsible, which was enshrined in feudal Europe and carried over into the early modern period (for instance, in the concept of the 'divine right of kings' which, for all its flaws, is a recognition that kings need more authority than their wealth and power can give them before they can act licitly), is lost in Enlightenment understandings of the state: Rousseau's famous 'social contract', for instance, is clearly a (rather desperate) attempt to place limits on the power of the sovereign (or the sovereign state) once belief that there are external limits has been lost. So is the concept of human rights. 
this might apply to God is not often asked, as far as I can discern, ${ }^{28}$ but the theological location of the answer is clear enough: law here clearly operates as some form of real universal, and the Christian tradition, whilst generally refusing to deny the existence of universals in its rejection of nominalism, has equally been unhappy about asserting their independent existence in full-blown realism. The solution, as I have argued elsewhere, ${ }^{29}$ is generally found in the doctrine of divine simplicity, which insists that universals are partial but accurate descriptions of the ineffable essence of God. On this reading the law that God cannot set aside is an aspect of his own nature; for God to set aside the law would be equivalent to God choosing not to be good; both are inconceivable. ${ }^{30}$

This argument seems to work, assuming the premise that the law that demands sin be met with satisfaction is accepted as a perfection of God's nature. I assume, therefore, that the criticisms of penal substitution are based not on an inability to sketch such obvious theological arguments, but on a denial of this basic premise. ${ }^{31}$ Rather than attempt a defence here, ${ }^{32}$ let me offer another line of response, based on Anselm's arguments, that I think demonstrates the need for satisfaction equally well.

On Anselm's telling, satisfaction is not demanded because of any need or lack in God. God is perfectly fulfilled - happy, if you will - in his own triune life, and it would be the height of sinful arrogance and proud presumption to imagine that the sins of the whole world could dent that perfection in the least way. Rather, for the creation to be what it was intended to be, it needs to honour God perfectly - and the same is true of every particular creature. If God is in fact honoured by monastic observance, or by liberative activity, then to be utterly devoted to such action is the necessary responsibility of

28 Paul Fiddes is an honourable exception, although his suggestion that law be equated with the will of God, rather than the being of God is, I think, a misreading of the tradition. Past Event, pp. 101-2.

29 See my 'Something Much too Plain to Say: Towards a Defence of the Doctrine of Divine Simplicity', Neue Zeitschrift für Systematische Theologie und Religionsphilosophie 43 (2001), pp. 137-54, reprinted with minor adjustments as ch. 4 of my Listening to the Past.

30 To conceive of them requires a suggestion that God's will and God's nature are no longer aligned, and so a suggestion that God has ceased to be holy (as the identity of God's will and God's nature is a standard definition of holiness). If God could cease to be holy he would no longer be God, but the most horrible demon. I owe this point to the Reverend Rufus Burton.

${ }^{31}$ If this is the case, however, it is something of a shame that they are not generally clearer about the point.

32 Although the basic lines of the defence I would offer will become clear later in the paper. 
every creature at all moments of its life. Thus, an ardent amendment of the whole of life, even if perfectly carried out, can only result in no further failure to honour God; the failure that had already happened remains. The creature has failed to be what it should be, and so is damaged, and this damage is irreparable by any creaturely action. Atonement is necessary, not to repair damage done to God, but to repair the self-harm done by the creature. God, being a se, cannot be damaged, and so has not been damaged.

Now, I realise of course that many modern critics of penal substitution would not accept such an account; but this is entirely beside the point; penal theories were developed by theologians who held to a traditional Christian doctrine of God, and so the model can only be attacked from within this tradition. If the complaint is in fact against the doctrine of God, then that is a different discussion, but to attack penal substitution because it makes no sense in a thought-world in which it was never intended to make sense is as idle as complaining about not getting a leg-before-wicket decision on a baseball diamond.

Even accepting all this, the complaint might be re-phrased: could God not simply act to make the creature whole by sovereign loving decree without any need for atonement or satisfaction? Anselm's arguments, however, explain why this cannot be: the creature's identity, established by a narrative continuity of actions, is what is broken and damaged: God might act to end that creaturely identity and create a new one out of the ashes, break the narrative continuity through some radical ending and beginning, a truly drastic version of being 'born again', but that would not be salvation, it would be destruction and new creation. For salvation to come, there somehow needs to be a single narrative continuity, a single personal identity, that contains within it not just the failures but that which re-establishes the creature as what it should be. In Anselm's terms, there is a need for satisfaction, for an element of the narrative through which the creature offers the honour to God that it needed, and failed, to give. I have already indicated that any attempt at the amendment of life cannot fulfil this criterion, as, at best, if perfection is reached it will only result in no more failure being added to the account. In such terms, the event of penal substitution is not merely a forensic declaration of the forgiveness of guilt extra nos, it is an event in the life of each saved person that transforms that life.

So, on such an account there is a need for satisfaction, not because God somehow demands it, but because the creature cannot be what it was created to be without it. Unless satisfaction is made, God's purposes for the creature would be thwarted. This does not yet establish that penal substitution is a valid way of making that satisfaction, but it does at least indicate that somehow it needs to be made. At this point I suppose that the argument 
I would offer to demonstrate the disputable premise in my first defence of the need for satisfaction is becoming clear: it is now at least plausible to suggest that God's faithfulness, goodness and constancy to the creation establish certain 'laws' of action that can be considered to be aspects of his being, because they are contained within these perfections.

On to the second of my four points, and the argument that penal substitution is an inadequate picture of what is going on at Calvary because it necessarily posits an improper separation between Father and Son. The Father is the angry God who demands blood, the Son the loving Saviour who offers his own to satiate the bloodlust of his Father. Father and Son are disunited - opposed even; their will, their intention, their desire and their attitude are at odds. This is the picture presented by penal substitution, and it is an improper one.

Let me first acknowledge the force of the complaint: if this were the picture presented by penal substitution, it would indeed be an improper one. Orthodox trinitarian theology has always insisted on the utter unity of the attitudes, actions, desires and intentions of the divine persons. Hence, John of Damascus: 'There is... one ousia, one goodness, one power, one will, one energy, one authority; one and identical; not three similar to each other, but a single identical motion of the three hypostaseis ...'33 There can be no room for such division in the Godhead. So any defence must deny the minor premise, must show that penal substitution does not, in fact, involve such a separation. Can my readings of Calvin and Anselm offer any help here?

Calvin's initial discussion of the subject, although devoted to clearing away a problem, should, I think, be read as programmatic. The great statement of these three sections is that God - and I think we should read the Father here, although the point is (necessarily) equally true of the whole Trinity - God's fundamental attitude is that he desires his people to be saved. Second to that is his abhorrence towards that which has put us in danger of perdition in the first place, our sins, rebellions, and failures. These points are demonstrated from Scripture at some length. Calvin does not turn to demonstrate that the Biblical presentation of the attitude of Jesus the Son is precisely the same, and I have not time to do it here, but I think it is a point sufficiently plausible to be asserted. That Jesus' first response is love, mercy, compassion to the sinner, and that within that is nonetheless an implacable hatred of sin, is an intuitively plausible reading of the gospels. On Calvin's account, then, Father

33 Quoted by G. L. Prestige in God in Patristic Thought (London: SPCK, 1952), pp. 263-4. As Prestige notes, John is quoting Ps.-Cyril at this point. He further argues that this is a summary of the position held by the Greek Fathers from Origen, citing Athanasius and the Cappadocians in particular. 
and Son are utterly united, and his doctrine - the classical statement of penal substitution - is defended on this basis. The second complaint, like the first, has no substance.

What of God's anger against sin, often dismissed as a primitive anthropomorphic conception of deity? Is it the case that God's hot anger, God's wrath burns against sinners, needing to be satisfied before it might be averted? I hope that some, at least, of the resources to answer this criticism are already obvious from the expositions of Anselm and Calvin I have offered, but let me pause for a moment to consider the form of the criticism, before sketching the defence. Two distinct complaints are generally wrapped up in this line of critique: can we legitimately describe God as angry, and even if we can, is it proper to speak of that anger as demanding satisfaction - the price of blood? Both these criticisms turn on Anselm's famous question of how serious a thing sin is. On the one hand, the sustained Biblical witness to the wrath of God is a witness that God regards sin as something serious. Not that God is in some pagan way offended or upset by sin - the basic orthodox condition of aseity still holds - but that God's anger burns against all that threatens to warp and destroy the creation he has made to love. It is in this sense that Barth's celebrated assertion about God's wrath being a form of his love must be taken on board: if God were merely indifferent towards his world, he would have no reason to be angry at sin. God's anger is the anger of an artist who, knowing she has created a masterpiece, sees fools desecrating it with felt-tip pens; it is the anger of a mother who sees abusers wounding, warping and destroying her child. ${ }^{34}$ To suggest that God is not angry is to suggest that this mother should not be either. God's anger cannot logically be denied without a simultaneous denial of God's love. ${ }^{35}$

On the other hand, there is the question of satisfaction. I have already indicated that exegetes are united in insisting the sacrificial system implied a worldview in which sin demanded satisfaction, and argued that the creature needs satisfaction to be made for there to be a possibility of its redemption; the traditional language, however, speaks of the wrath of God being satisfied.

34 This aspect of the traditional doctrine of God has been recaptured by the liberation theologians, and other contextual theologians, after many years of a liberal theology that, at its worst, seemed to be devoted to proving that sin is not a problem and that God is far too nice ever to be angry. The most powerful statement of this theme is perhaps Robert Beckford, God of the Rahtid: Redeeming Rage (London: DLT, 2001).

35 A previous service book issued by the denomination within which I have the privilege to minister, the Baptist Union of Great Britain, suggested a form of marriage vows that included the promise 'I will love you when I love you and when I hate you.' The gloss pointed out that the opposite of love is not hatred, but indifference. The point is profoundly right, although arguably out of place in a wedding ceremony. 
Can this be defended? It seems to me not only that it can but it must; if satisfaction is understood as I have described it, as a reordering of the identity of the creature that is necessary for the creature to be what it was determined by God to be. On the premise that God's purposes are omnibenevolent, then whatever the creature was purposed to be by God is the best thing it can possibly be; any alternative identity is a falling short on the creature's part of what it could be. I have already argued that to speak of God's anger is to speak of God's loving concern that a creature be all that he desires it to be; if this is the case, and if a creature cannot be that without satisfaction, then God's anger demands satisfaction.

Now, this may seem some way from traditional accounts of penal substitution, but that is not the case. In my exegesis of Anselm I showed that it was precisely God's benevolence, his desire for the best for his project of creation, that meant punishment of sinners was unthinkable, and that satisfaction for sin would have to be somehow made instead. In reading Calvin, I pointed out that his first discussion on the atonement concerns the recognition that the love of God must be the first and basic reality, or atonement would never have happened. So the classical accounts of penal substitution have precisely the primary focus on the love and goodness of God that I have been developing here.

But still, why this satisfaction? Why torture and scorn and mockery and public spectacle and bloodshed and anguish and the cruellest of deaths? ${ }^{36}$ Here, Anselm's account is inadequate: he argues that satisfaction can only be made by the offering of a gift God could not demand, and that the life of the sinless God-man was such a gift. But there is nothing in the argument to explain why a private and painless suicide, the dignified death of Socrates, would not have sufficed. Calvin's account is more satisfactory: the public trial, condemnation and execution of Christ have a purpose: they reveal that he is standing in our place, being judged and condemned on our behalf. Again, the agonies he suffers are images of the spiritual agony, the descent into hell, that he bore for us on the cross, and so must happen for us to know and understand what he is doing for us. This is a place where Calvin's full-blown penal scheme has the advantage on Anselm's earlier account: the public shame and agony of Christ make perfect sense if we understand what is going on as a judicial process. This leads to the final complaint: can, in fact, this be understood as a judicial process? Can it be just for the sinless one to be punished on our behalf?

${ }^{36}$ Whatever the theological or cinematic merits of Mel Gibson's recent The Passion of the Christ, it makes this point at least with considerable power - as does the medieval Catholic tradition of devotion from which the film so obviously borrows. 
This is perhaps the most lasting complaint. It is suggested that this is simply not justice. That no court in the world would let a criminal go free if someone else offered to serve their sentence for them, to be imprisoned on their behalf, or to be executed in their place. This instinct is, I think, not as obvious as is sometimes made out: if the court's punishment is a fine, then the court will obviously be satisfied if the fine is paid, whether it is paid out of the criminal's savings or whether some generous benefactor for reasons of her own chooses to give the criminal the money to pay. And it is worth remembering that many penalties were traditionally commutable to fines in European law, even penalties for murder. We are not, however, talking about a fine when we come to the atonement; we are talking about an execution. I have already suggested that Anselm's attempt to describe the death of Christ as a gift offered to God is inadequate, in that it does not explain the death Christ died. Can someone else take my place on the cross?

I suggested that there was a sense in which Anselm's account was not straightforwardly substitutionary, in that his account depends on the created order, albeit focused in one of its members, offering to God the satisfaction, the honour, that he was due. It seems to me that this intuition might suggest a way forward: the penal tradition was perhaps most dominant in the context of a theological scheme, covenant theology, that pictured a very close connection between Christ and his people. In certain statements of this theme Christ is deemed (like Adam) to be a 'corporate personality' or 'public person'; through which some formal identity was postulated between Christ and the Church, and between Adam and all human beings. ${ }^{37}$ Such reflections suggest two questions: could it be any more just for Christ to offer himself in our place if such a connection exists, and what form might this connection need to take?

On the first, I think that it is at least possible that this might be the case: consider the moral imagination that in many cultures has regarded it as just to punish a wife for her husband's actions, a father for his children's, and so on much more widely through the family circle. This is not the way people in the West tend to conceive of morality, rather imagining ourselves as utterly individual agents whose choices are not affected by others, and who are thus not responsible for the choices of others. But we have surely learnt by now that the first part of that is merely a fiction, that it is of the essence

37 William Ames asserts 'it is the church of Christ because it is united to Christ ... the elect... are grafted into Christ' (Marrow of Theology, trans. and ed. John D. Eusden (Grand Rapids, MI: Baker, 1997), p. 175. For an extended and powerful statement of this theme, see John Gill, A Body of Doctrinal Divinity (London, 1795), Book 2, ch. IV. Gill quotes several earlier writers, and many other examples could be offered. 
of personal agency not to be utterly individual, and so that our choices are necessarily affected by others. Given this, is the widespread intuition that we can be held responsible for the actions of those to whom we are closest, not at least worthy of consideration? And if we begin to imagine this, is not penal substitution more comprehensible?

I offer these analogies in the hope that they make the underlying logic of penal substitution, that one person may in fact bear another's penalty, less totally unimaginable. I realise, of course, that all this is not enough; but so did the tradition that taught penal substitution at various points in its history. In later Reformed thought, there is a concerted attempt to offer a theological logic whereby Christ and the Church can be treated as a single moral agent. Two versions of this were common: offering a federal account of the union, or offering a realist account. ${ }^{38}$ I have already noted that Anselm's logic moves in these directions, positing an action which restores the moral status of the created order through one of its members, the God-man, Jesus of Nazareth. However, this is not a penal account, and so inadequate to my present purposes.

The federal tradition, or covenant theology, argues in effect for a 'legal fiction' decreed by God (although, of course, nothing decreed by God can be rightly considered a fiction). On this account, God so establishes the natural order that all human beings will be held accountable for the moral actions of Adam, and all members of the Church will be jointly accountable with the head of the Church, Christ. So the sin of Adam is justly imputed to all other human beings, but Christ's bearing of the penalty is sufficient satisfaction for the guilt of the members of his Church. The realist tradition attempts to demonstrate that this is no legal fiction, but a state of affairs which is a necessary result of the relationships that obtain within the world. I have given an account of Jonathan Edwards's doctrine of original sin elsewhere, ${ }^{39}$ which works on these terms: Edwards effectively offers a philosophical argument that, if it is correct, establishes that Adam's actions are as much mine as my own are, and that my actions are as much Christ's as they are mine. He does this through a theological account of identity which I suspect does not work, but that is beside the point in a sense: the failure of one particular argument does not demonstrate that the position is unsustainable, and so it remains possible that such an account might work.

${ }^{38}$ I have been helped on this point by a paper written by one of my doctoral students, the Reverend Wilfred Ho Wai Tat.

39 See my God of Grace and God of Glory: An Account of the Theology of Jonathan Edwards (Edinburgh: T\&T Clark, 2000), pp. 227-31. 
Finally, however, on this point, it is worth asking why did Calvin not even worry about the question of whether one person could be punished on behalf of another: his account depends on this position, and yet he does not address it as an issue. I think there are two elements to why this is the case: first, I am sure that the problem was not so sharp for Calvin, in that he was not hung up on modern individualistic and atomistic accounts of ethics which insist as a primary position that my actions are mine and mine alone; ${ }^{40}$ second, I suspect that Calvin's account is driven by an exegetical logic which makes this a non-problem: Calvin believes that one of the ways the Scriptures illuminate the work of Jesus is through an account of substitutionary guilt bearing: this is the logic behind the entire sacrificial system, apart from anything else. Given this, the question of whether a substitute can in fact bear another's guilt is not an issue: in God's economy, this happens, so it must be possible for it to happen.

\section{Conclusion}

So, I have sought to sketch how an argument for the continued relevance of the tradition of penal substitution might proceed. I suppose the final question is, why bother? Is there any merit in rescuing this tradition? Let me in conclusion briefly mention three reasons:

First, I have already suggested that a large part of the hymnody, liturgy and devotional writing of Reformed and Evangelical Christianity has stressed penal language in its discussion of the atonement. If the only result of a defence of penal substitution is that this material remains available to us, then that already means the argument is worth making.

Second, in sketching an account of how we should develop an atonement theology, I have suggested, albeit briefly, that each additional model or metaphor we are able to deploy enlarges our understanding of what was done for our salvation at Calvary. If this is the case, then to demonstrate that a model that has been widely rejected as misleading or inaccurate is in fact useful is a theological advance.

Third, and most importantly, however, it seems to me that penal metaphors are important because they take the reality of sin seriously. Typically, modern accounts of the atonement are tinged by liberation theology, and suggest that the essence of sin is some form of oppression, and that Christ's bearing of the ultimate in oppression on the cross, and his victory over that, is God's decisive act of rejection of all oppression. On this basis, the cross speaks liberation to the oppressed, and judgement on the oppressors. The

40 Calvin demonstrates that the concomitant to this, a libertarian view of freedom, is incoherent. Inst. II.2-5. 
account given of repentance is a turning from being an oppressor to side with the oppressed, and so a participation in God's liberative action. Such recognitions are important, but they ignore Anselm's great insight: half a lifetime of oppression, of rebellion against God, cannot be simply forgotten, as I have argued, both exegetically and theologically, at some length earlier. A key element of penal substitution is language of acts of transgression crimes - and the guilt they bring, which must be dealt with. Thus, penal substitution is a way of talking that speaks of the cross to the oppressors, to those who damage and kill. It speaks a word of deep criticism - Barth's insight that only the cross shows us just how abhorrent our actions are - a word of decisive judgement that is still, nonetheless, a word of hope, of life beyond judgement.

In the gospel accounts of the crucifixion, there are two moments of individual salvation. One is the penitent thief, who, whatever his crimes, is one of the oppressed, victimised by the cruel Roman occupiers. Modern accounts of atonement can make sense of his deliverance. The other, however, is the centurion in Mark, the oppressor, the invader who persecutes the thiefand who persecutes Jesus, the blameless Son of God. Penal substitution is, I suggest, a way of making sense of this moment of salvation.

Historically, penal accounts arise within the activist spirituality of Reformation and Evangelical traditions, and flourish amongst the Christian traditions of colonial Europe. As such, they were perhaps an appropriate theology of the cross for their day, speaking radical critique and judgement on the actions of European oppressors, and announcing that no outrage, however much it was hidden by further exercises of power, would have its guilt covered over and forgotten. This was a deeply prophetic theology - but beyond that word of judgement was also a word of hope, a promise that the foulest oppressor might be liberated from the crushing guilt of his or her misdeeds and provided a place with the poor and the oppressed at the Messianic feast. Penal metaphors matter, finally, because they teach us just how serious our plight was, and so just how much God has graciously done in Jesus. To return once more to Bliss's great hymn, 'Guilty, vile and helpless we; spotless Lamb of God was he; full atonement - can it be? Allelujah! What a Saviour!' 